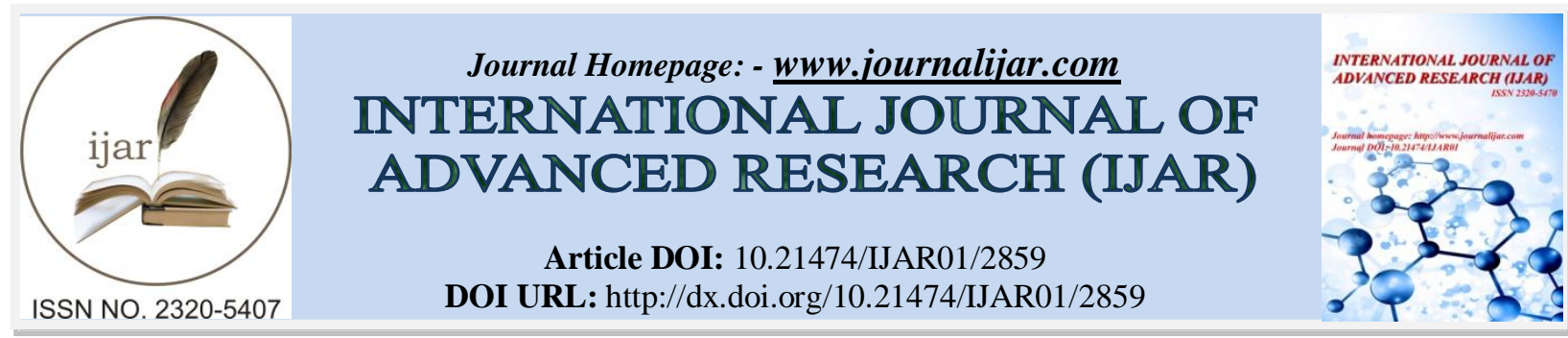

RESEARCH ARTICLE

\title{
ALPINIA CALCARATA: A NEW DISTRIBUTIONAL RECORD IN THE ZINGIBERACEAE FLORA OF MANIPUR
}

\author{
Ningombam Babyrose Devi ${ }^{1}$, Ajit Kumar Das ${ }^{1}$ and P.K. Singh ${ }^{2}$ \\ 1. Department of Ecology and Environmental Sciences, Assam University, Silchar, Assam. \\ 2. Centre of Advanced Study in Life Sciences Department of Life Sciences, Manipur University, Chanchipur, \\ Imphal, Manipur.
}

\section{Manuscript Info}

\section{Manuscript History}

Received: 21 November 2016

Final Accepted: 21 December 2016

Published: January 2017

Key words:-

Flora, Manipur, new record,

Zingiberaceae

\section{Abstract}

The present paper includes Alpinia calcarata Roscoe as a new record in the Zingiberaceae flora of Manipur. The plant is described along with the field photographs.

\section{Introduction:-}

Zingiberaceae is considered as one of the most important and valuable group of monocots. It is a well-known plant family for its medicinal and economic significance ${ }^{5}$. They are mostly distributed in tropical and sub-tropical region of the globe with maximum distribution in South East Asia. ${ }^{4,6}$

Manipur is situated in the north-east India and is centrally located on the eastern arm of the Himalayas- Purvanchal consisting of a valley embosomed in the mountainous region. The specimen was observed during the field survey in the valley districts in 2016. Detailed studies were undertaken with the various floras and herbaria and is subsequently identified as Alpinia calcarata Roscoe. The collection forms a new distributional record in the Zingiberaceae flora of Manipur.

\section{Taxonomic treatment:-}

Alpinia calcarata Roscoe- Trans. Linn. Soc. London 8: 347. 1807 (IK)

Pseudostem to $1.3 \mathrm{~m}$; leaves sessile; ligule $0.8-1.2 \mathrm{~cm}$, glabrous, apex obtuse bilobed; leaf blade linear, lanceolate, 25-33 x 2.5-3.7 cm, glabrous, green, base attenuate; leaf margins with short bristles; panicle $11.2 \mathrm{~cm}$, rachis velvety; proximal branches 3 flowered; bracteoles membranous, apex obtuse, $1.4 \mathrm{~cm}$ long; pedicel $3 \mathrm{~mm}$, pubescent; calyx apex 3-toothed, pubescent, $1.2 \mathrm{~cm}$, split on 1 side, white in colour; corolla white, glabrous, obtuse, lobes oblong, 2 shorter, $1.8 \mathrm{cmx} 0.5 \mathrm{~cm}, 1$ larger, $2 \mathrm{~cm} \times 0.9 \mathrm{~cm}$; lateral staminodes red, subulate, $3 \mathrm{~mm}$, adnate to the base of labellum; labellum white with cherry red streaks, obovate, apex emarginated, $3.3 \mathrm{~cm} \times 2.4 \mathrm{~cm}$; stamen $2.2 \mathrm{~cm}$; anther dorsifixed, bilobed, $0.7 \mathrm{~cm}$, filament slender slight pinkish at the base, $3.3 \mathrm{~cm}$; stigma capitates; presence of 2 oil glands, yellow, $0.2 \mathrm{~cm}$; capsule globose, pubescent; ovary trilocular.

Corresponding Author:- Ningombam Babyrose Devi.

Address:- Department of Ecology and Environmental Sciences, Assam University, Silchar, Assam. 


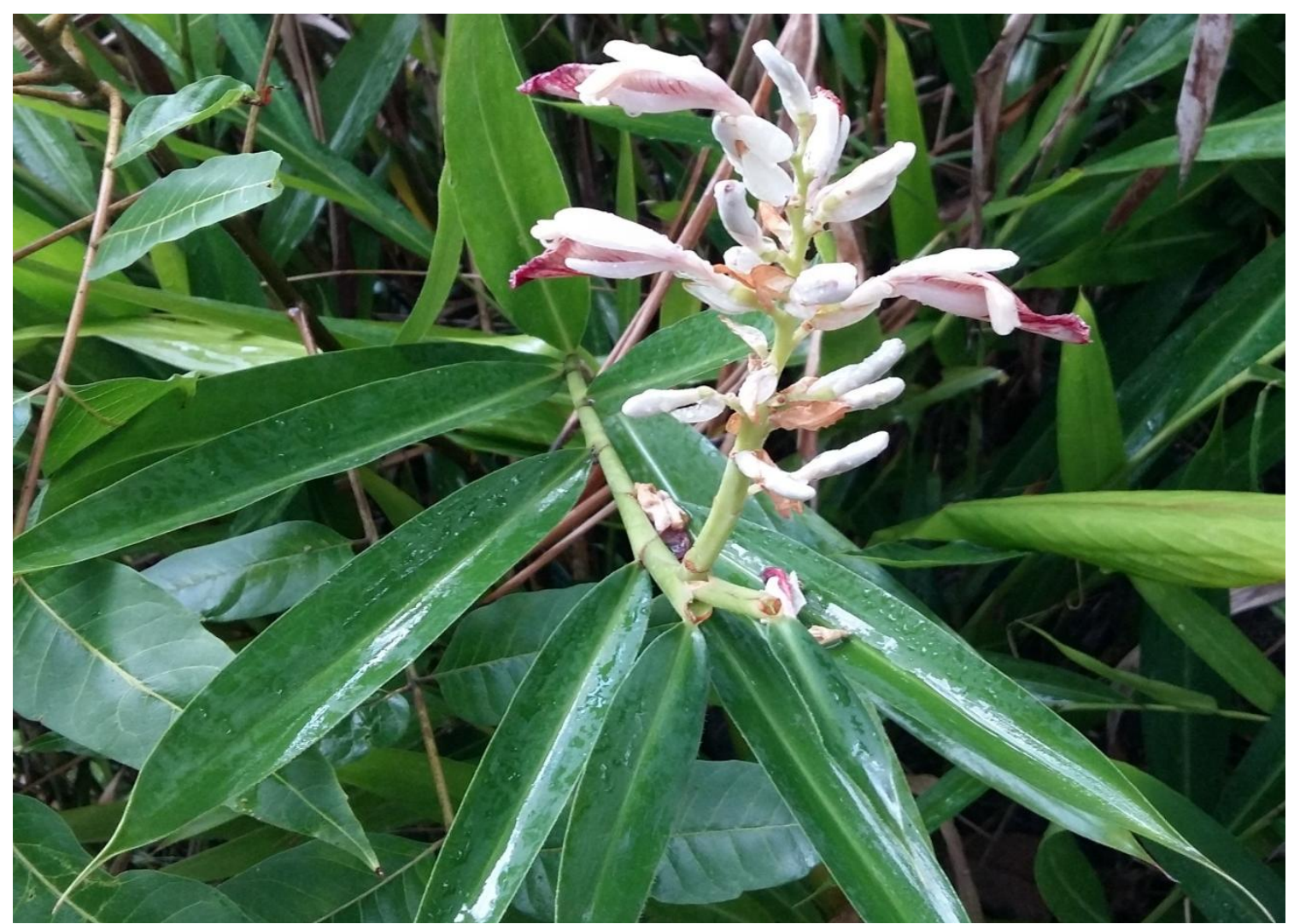

Fig.1:- Alpinia calcarata Roscoe in the natural habitat.

\section{References:-}

1. Baker, J.G. (1892) Zingiber. In: Hooker, J.D. (ed) Flora of British India 6: 243-249.London: L. Reeve and Co.

2. Deb, D.B. (1961) Monocot and Dicot plants of Manipur 3: 119-120.

3. Karthikeyan, S., Jain, S.K., Nayar, M.P. and Sanjappa, M. (1989) Zingiberaceae. In:Florae Indicae Enumeratio- Monocotyledonae. 289-299. Calcutta: Botanical Survey of India.

4. Larsen,K. and Delin, W. (2000) Flora of China 24:322-377.

5. Rahman, M.A., Islam, M.S. (2015): Alpinia calcarata Roscoe: A potential phytopharmacological source of natural medicine. Phoog Rev 9: 55-62

6. Ramesh, K., Singh, S.K., Sharma, S. and Mao, A.A(2013) New and noteworthy records of Gingers from North-east India. Keanean Journal of Science (2): 13-18

7. Roxburgh, W. (1810) Description of several of the monandrous plants of India. Asiat. Res. 11: 318-362.

8. Roxburgh, W.(1820) Flora Indica. Serampore: Mission Press. 